Acta medico-historica Rigensia (1999) IV: 285-314 DOI: 10.25143/amhr.1999. IV.20

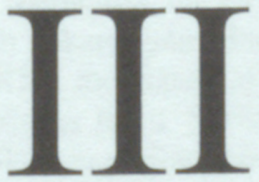



Arnis Vīksna

\section{LATVIEŠU ĀRSTI, LATVIJAS ARMIJAS ĀRSTI UN LATVIJAS UNIVERSITĀTES MĀCĪBSPĒKI, KAS PẼTERBURGAS KARA MEDICĪNAS AKADĒMIJĀ STUDĒJUŠI, PAPILDINĀJUŠI ZINĀŠANAS, STRĀDĀJUŠI VAI AIZSTĀVĒJUŠI DISERTĀCIJAS LĪDZ 1918. GADAM}

Ievads

Pēterburgas (Petrogradas) Medicīnas un ķirurgijas akadēmija dibināta 1798. gadā pulka dziednieku (lekarj) gatavošanai ar četrgadīgu apmācỉbu, 1881. gadā pārsaukta par Kara medicīnas akadēmiju (PKMA) ar piecgadīgu kara ārstu sagatavošanas laiku. Savulaik tajā strādāja slavenais Nikolajs Pirogovs, starp izcilākiem profesoriem jāmin arī kīmiḳi N. Zinins, A. Borodins, biologi N. Holodkovskis, J. Pavlovskis, anatomi un histologi P. Zagorskis, V. Grūbers, V. Tonkovs, A. Zavarzins, A. Maksimovs, fiziologi I. Sečenovs, I. Pavlovs, L. Orbeli, farmakologi N. Kravkovs, S. Aničkovs, higiēnists G. Hlopins, mikrobiologs D. Zabolotnijs, patologi M. Rudnevs, V. Pašutins, N. Aničkovs, ķirurgi N. Sklifosovskis, N. Veljaminovs, V. Opels, S. Fjodorovs, H. Turners, V. Ševkunenko, V. Šamovs, terapeiti S. Botkins, N. Čistovičs, M. Arinkins, neirologi un psihiatri S. Meržejevskis, V. Behterevs, pediatri S. Hotovickis, M. Maslovs, otorinolaringologs N. Simanovskis, dermatovenerologs T. Pavlovs u.c.

Akadēmijai bija augsts prestižs, Krievijas armiju tā apgādāja ar labiem speciālistiem. Pastāvēja liels iestājkonkurss, bet studijas arī nepārtikušu vecāku dēliem tika materiāli nodrošinātas, pēc tam noteikts laiks bija jāatkalpo militārdienestā. Tāpēc uz akadēmiju tiecās ar̄̄ latviešu jaunekli. Tuvāka gan bija Tērbatas Universitāte, kurai arī bija augsts zinātnisks prestižs, turklāt tā 19. gadsimtā un 20. gadsimta sākumā deva aptuveni desmit reizes vairāk latviešu ărstu nekā PKMA. Toties profesoru īpatsvars starp latviešu absolventiem PKMA ir ievērojami augstāks. Maskavas universitāte deva aptuveni tikpat vai pat nedaudz vairāk latviešu ārstu nekā PKMA, taču vinuu vēlākā darbỉba mazāk redzama.

Šo têmu pirmais aplūkot un apkopot centās profesors Jēkabs Prīmanis, PKMA audzēknis, jau atrodoties emigrācijā. Viṇa apcerējums ir ar̄̄ paliekošā vērtỉba šai zin̄ā, publicēts 1970. gadā N̦ujorkā [1]. J. Prīmanis 
galvenokārt balstijjās F. Mīlenbaha 1908. gadā izdotā sarakstā [2], personiskās atminas un korespondences ceḷā (arī no Latvijas kolēgiem) iegūtos datos. Protams, dažādas nepilnības un neprecizitātes nebija novēršamas. Taču tas nemazina J. Prīmaña veikumu.

Par vina ieroses atspulgu uzlūkojamas jau 1963. gadā Rīgā publicētâs K. Arona tēzes [3], ko vēlāk papildināja A. Vỉksna [4] un kopā ar K. Aronu īsumā rezumēja [5]. J. Prīmaña apcerējums atkārtoti tika publicēts 1994. gadā Rīgā, taču nekorigèejot tekstu un izlīdzoties ar īsiem ievadvārdiem [6]. Atzīstot J. Prīmana nopelnus, turpmākā tekstā sniegtas īsbiogrāfijas un papildinājumi no Latvijā pieejamiem avotiem un publicētās literatūras, kas viñam nebija pieejama. Tas arī šã apkopojuma mērkis.

Personāliju aptveres loks bija saistīts ar vairākiem apsvērumiem, diskutējamiem momentiem un kompromisa meklējumiem. Vispirms, tie ir latvieši, kas absolvējuši PKMA (sekojot J. Prīmanim, tikai tie, kas iestājušies līdz 1918. gadam) vai arī tur studējuši un vēlāk beiguši LU vai citu augstskolu. Otrkārt, ieklauti cittautỉbnieki, kas saistīti ar PKMA un vēlāk bijuši LU profesori, kā arī Latvijas armijas ārsti. Treškārt, tie ir LU profesori un docenti, kas gan PKMA nav studējuši, toties tur aizstāvējuši disertācijas (tostarp viens farmaceits).

Bet tēma PKMA un Latvija ir daudz plašāka un še grūtāk aptverama. Jo loti daudzi PKMA absolventi (gan tikai retos gadījumos latvieši) 19. gadsimtā un 20. gadsimta sākumā bija Latvijas teritorijā dislocēto karaspēka vienỉbu un hospitālu ārsti, tāpat ienēma dažādus administratīvus amatus, strādāja civilās medicīnas iestādēs un privātpraksē. Tas būtu cita, daudz plašāka apcerējuma uzdevums.

Netiek aplūkota arī tēma par PKMA saistību ar korporāciju "Fraternitas Petropolitana" (vēlāk "Fraternitas Metropolitana"). Vairums (bet ne visi) PKMA latviešu audzēknu bija tās filistri. Tālab jāpievienojas viedoklim, ka korporācija ir interna organizācija, kas necenšas iespaidot sabiedrỉbu un atturas paust savus centienus ārienē.

Izmantoto avotu loks, īsbiogrāfijas shēma, kārtojums, hronologija noprotama no turpmākā teksta. Noslēgumā minētas diskutējamas personas, ievērojot J. Prīmaña apcerējumu un dažus papildinājumus. Lai šis darbs noderētu kā neliels klātnesums J. Prīmaņa veikumam un vēl turpmāk veicamam. 
1. Prīmanis $J$. Pēterburgas Kara medicīnas akadēmijas nozīme medicīnas attīstỉbā Latvijā // Universitas. - 1970. - 26. nr. - 42. - 51. lpp.

2. Mĩlenbahs $F$. Latvieši un latvietes Krievijas augstskolās. - Jelgava, 1908.

3. Aron K.J. Rol Peterburgskoi Vojenno-medicinskoi akademii v razvitii medicinskoi nauki v Latvii // Naučnie svjazi Pribaltiki v XVIII - XX vv. - Riga, 1963. - S. 223 - 226.

4. Viksna A.A. O pervih latišskih professorah-medikah - vospitannikah otečestvennih medicinskih škol // Voprosi medicini i biologii Pribaltiki. - Tartu, 1977. - S. 120-123.

5. Arons K., Vìksna A. Pēterpils Kara medicīnas akadēmijas loma militārmedicīnas izveidē Latvijā // Pasaules latviešu ārstu 2. kongresa tēzes: 3. d. - Rīga, 1993. - 11. lpp.

6. Prīmanis J. Pēterburgas Kara medicīnas akadēmijas nozīme medicīnas attīstỉbā Latvijā // Acta Medico-Historica Rigensia. Rìga, 1994. - Vol. 2. - 221.-239. lpp.

\section{Tekstā lietotie iestāžu īsinājumi}

LĀB Latviešu ārstu biedriba

LMA Latvijas Medicīnas akadēmija

LU Latvijas Universitāte

LVU Latvijas Valsts universitāte

MZA Medicīnas zinātnu akadēmija

PKMA Pēterburgas (Petrogradas) Kara medicīnas akadēmija

RMI Rīgas Medicīnas institūts

TU Tērbatas universitāte

U universitāte

ZA Zinātnu akadēmija

\section{Literatūras un avotu īsinājumi}

A $\quad$ Alks Dz. Latvijas mediḳi politisko represiju dzimās 1940. 1953.g. - Rīga, 1993. [Norādīta lpp.]

BK Brennsohn I. Die Aerzte Kurlands. - Riga, 1929². [Norādìta lpp.]

BL Brennsohn I. Die Aerzte Livlands. - Mitau, 1905. [Norādìta lpp.] 
EVP Es vipu pazīstu. - Rīga, 1939. [Norādīta lpp.]

İsi par kara medicīnas vēsturi un dažiem kara ārstiem, veterinārārstiem un farmaceitiem. - Rīga, 1993. [Norādīta lpp.]

JP Jēkabsons $\bar{E}$. Latvijas armijas ārsti, farmaceiti un veterinārārsti pulkveži // Latvijas Ārsts. - 1992. - Nr. 4. - 427. - 429. lpp.

LAAV Latvijas Armijas augstākie virsnieki. - Rīga, 1998. [Norādīta lpp.]

LĀP Latviešu ārsti pasaulē. - Rīga, 1993. [Norādīta lpp.]

LĀS Latviešu ārstu saraksts 1914. gadā. - P. Stradina Medicīnas vēstures muzeja Rokrakstu un dokumentu sektors.

LMP Latvijas medicīniskā personāla saraksts: 1921-1940, 1943. Rīga, 1921-1940, 1943. [Norādīts gads.]

LUX Latvijas Universitāte. - Rīga, 1929. [Norādīta lpp.]

LUXX Latvijas Universitāte divdesmit gados: 2.d. - Rīga, 1939. [Norādīta lpp.]

LVVA Latvijas Valsts vēstures arhīvs.

M Mĩlenbahs $F$. Latvieši un latvietes Krievijas augstskolās. Jelgava, 1908. [Norādīta lpp.]

MĀ Mirušo ārstu saraksts (1914-1938). - LVVA, 4578.f., 3.apr., 70.1., 1.-12. Ip.

P Prīmanis J. Pēterburgas Kara medicīnas akadēmijas nozīme medicīnas attīstībā Latvijā // Universitas. - 1970. - Nr. 26. 42.-51.lpp.; pārpublicējums: Acta Medico-Historica Rigensia. - Rīga, 1994. - Vol. 2. - 221.-239. Ipp. [Norādīta pārpublicējuma lappuse.]

PĀT Vĩksna A. Pa ārstu takām. - Rīga, 1990. [Norādīta lpp.]

PME Populārā medicīnas enciklopēdija. - Rīga, 1985³ ${ }^{3}$. [Norādīta lpp.]

RMS Rossijskij medicinskij spisok: 1890-1916. - SPB., Pg., 18901916. [Norādīts gads.]

Š Šaurums G. Tērbatas universitāte. - Rīga, 1932. [Norādīts studenta kārtas numurs.]

V Vìksna A. Medicīnas sākumi Latvijas novados. - Rīga, 1993. [Norādīta lpp.] 


\section{Jēkabs Alksnis}

Dzim. 22. aug. 1870 Durbes pag. zemnieka ġim. Beidza Liepājas Nikolaja gimnāziju 1890. Stud. TU 1890-95, ārsts. Kara ārsts 1897-1910, 1914-18, piedalījās Krievijas un Japānas un Pirmā pasaules karā. PKMA Dr.med. 1907, disertācija "Operacii na pojasņično-tazovoi časti močetočnika $i$ ih funkcionalnie rezultati". Ārsts un privātklīnikas īpašnieks Liepājā 1908-14, 1918-20. Latvijas armijas ārsts 1919-20, pulkvedis. LU docētājs 1920-40, Fakultātes ķinurgijas kat. vadìtājs. 1924 40, Med. fak. dekāns 1931-33, profesors 1924. "Latvijas Ārstu Žurnāla" dibinātājs un redaktors 1923-39, 1942-44. LĀB priekšnieks 1929-32. Pēc 1944 Vācijā, no 1948 Anglijāa Pētījumi urologijāa, vēderdobuma kirurǵijā un latviešu tautas medicīnā. Apbalvots ar Triju Zvaigžņu ordeņa 3. un 2. škiru, kā arī 4 Krievijas ordeņiem. Kauñas U Dr.med.honoris causa 1933. Miris 7. martā 1957 Londonā, pīšli pārapbedīti Rīgas Meža kapos 1995. Piemiñas plāksne Graudu ielā 28 Liepājā 1990.

Darbi: Materialien zur lettischen Volksmedizin. - Halle, 1894.

Vēres: İ 18; LAAV 65-66; LĀP 10; LUXX 399-404; LVVA 7427. f., 13. apr., 44.1; PĀT 64-65; V 152; Prof. Dr.med. Jēkabs Alksnis. Vesterosa, 1970.

\section{Fricis Andreika}

Dzim. 29. jūl. 1891 Elejas pag. Beidza Jelgavas ǵimnāziju 1911. Stud. PKMA 1911-13, TU 1913-16, beidza LU 1924. Ginekologs Rīgā, Alūksnē, Saldū. Pēc 1944 Vācijā, no 1950 ASV. Miris 21. sept. 1968 Sietlā.

Vēres: LĀP 11; P 228; Š 1026.

\section{Aleksandrs Balodis}

Dzim. 1872. Beidza PKMA 1896. Kara ārsts Pavlogradā un Kazan̄ā, pulkvedis.

Vēres: LĀS; M 27; RMS 1905, 1914.

\section{Hermanis Bērziñš}

Dzim. 20. jūn. 1882 Rozēnu pag. Stud. TU 1903-04, PKMA 1904-09. Kara ārsts Vladivostokā. Miris pirms 1914.

Vēres: LĀS; M 128; RMS 1911, 1914. 


\section{Hugo Bērziṇš}

Dzim. Alūksnē. Beidza PKMA. Kara ārsts. Miris pirms 1914. Salīdzināt ar Hermani Bērziṇu.

Vēres: LĀS; M 29; P 224.

\section{Jānis Bērziñš}

Dzim. 1875 Pleskavā. Stud. PKMA 1895-1900, ārsts. Dr.med. Krievijas armijas ārsts, dienēja Polijā, pulkvedis. J. Prīmanis vinuu jauc ar Jēkabu Bērziṇu.

Vēres: LĀS; M 29; P 225; RMS 1914, 1916.

\section{Jēkabs Bērziṇš}

Dzim. 9. aug. 1873 Kapsēdes pag.zemnieka gim. Beidza Nikolaja ġimnāziju Liepājā 1890. Stud. TU 1892-97, ārsts. Krievijas armijas ārsts 1898-1918, papildinājās PKMA 1908-11, 1. latviešu strēlnieku brigādes ārsts 1916-18. Vēlāk Sarkanarmijā, Latviešu strēlnieku padomju divīzijas sanitārās daḷas vadītājs. Latvijas armijas ārsts un Liepājas kara slimnīcas priekšnieks 1921-31, pulkvedis. Apbalvots ar Triju Zvaigžņu ordeña 4. šķiru un 5 Krievijas ordeņiem. Miris 12. martā 1935 Liepājā.

Vēres: BK 89; Ī 19; LAAV 101-102; Š 517.

\section{Frīdrihs Biezais}

Dzim. 17. sept. 1882 Valmieras apr. Beidza gimnāziju Pēterburgā un PKMA 1907. Turpat asistents, 1908-14 Novorosijas U Odesā. Kara ārsts 1914-18. Docētājs Odesā 1918-22, no 1922 LU. Pētīja rentgenstarojuma ietekmi uz sarkaniem un baltiem asinsḳermenīsiem u.c. Miris 31. dec. 1925.

Vēres: LVVA 7427. f., 13. apr., 193. 1.; MĀ; P 224; Latvijas Ārstu Žurnāls, 1925, 11./ 12. nr., 308.-309. Ipp.

\section{Jēkabs Biezais}

Dzim. 1891. Beidza PKMA 1915. Ārsts Sabilē. Miris ap 1940. Vēres: BK 96; LMP 1928, 1940. 


\section{Jēkabs Bullis}

Dzim. 22. aug. 1852 Glebavā, Kauṇas gub., zemnieka gim. Beidza Jelgavas gimnāziju. Stud. TU 1873-74, PKMA 1874-75, Kijevas U, ārsts 1880. Ārsts Bauskā un Baldones kūrvietā 1881-83, Jelgavā no 1883 , arī Jelgavas Latviešu biedrības priekšnieks, Kurzemes biškopības biedrības priekšnieks un laikraksta "Tēvija" redaktors. Literāros darbus publicēja ar pseidonīmu Ziediṇš. Miris 26. sept. 1887 Jelgavā.

Vēres: BK 120; EVP 104; M 8; Š 160; Zeiferts T. Latviešu rakstniecỉbas vēsture. - Rīga, 1925. - 3. d. - 11. lpp.

\section{Jānis Bune}

Dzim. 22. maijā 1891 Jaunsaules pag. bezzemnieka gim. Beidza Smoḷenskas gub. Roslavlas gimnāziju 1909. Stud. PKMA 1909-14, ārsts. Kara ārsts Rietumu frontē 1914-18, Sarkanarmijas ārsts 191822. Nikolo-Pogorelovas un Jarcevas slimnīcas galv. ārsts 1922-28. Samarkandas slimnīcas galv. ārsts 1928-30. Rokfellera fonda stipendiāts Tỉbingenē. LLeningradas 2. med. inst. un Maskavas 2. med. inst. asistents 1931-37. Kurskas med. inst. kat. vad. un direktors 1937-41. Sarkanarmijas ārsts 1941-45, arī Stalingradas frontes evakuācijas bāzes galv. kirurgs, pulkvedis. Pēc tam iepriekšējos amatos Kurskā 1945-47. Med. zin. dokt. 1946, disertācija "Par galvas smadzeņu cietā apvalka plastiku un smadzeņu defekta aizpildīsanu" (krievu val.), profesors 1947. LVU un RMI Vispārējās kirurğijas kat. vad. 1947-69. Pētijumi smadzeṇu ķirurgijāā, traumatologijiā, asinsvadu ķirurgijāa, ieteica operāciju taisnās zarnas izkrišanas novēršanai. LPSR Nop. bag. zin. darbinieks 1954. Miris 14. jūl. 1973 Rīgā, apb. Asaru kapos Jūrmalā.

Darbi: Ķirurǵija. - Rīga, 1952; Rīga, $1962^{3}$.

Vēres: LMA arhīvs, 7. apr., 2068. 1.; PĀT 110-111; PME 579; Veselỉba, 1959, 4. nr., 7.-8. Ipp.; 1961, 6. nr., 9. Ipp.

\section{Edvīns Bušs}

Dzim. 26. febr. 1873 Blīdenes pag. kalēja ǵim. Beidza Kuldīgas ġimnāziju 1891. Stud. PKMA 1893-98, ārsts. Dienēja Rịgas dragūnu pulkā, piedalījās Krievijas un Japānas karā. PKMA 
docētājs 1905-24, Dr.med. 1913, disertācija par sifilisa izraisītām pāmainām vairogdziedzerī. Kirurgs Leṇingradā 1924-35. L̦eningradas 3. med. inst. Fakultātes kirurgijas kat. vad. 1935-40, profesors 1935. Leningradas Jūras kara med. akadēmijas kat. priekšnieks no 1940. Pētījumi vēderdobuma un endokrīnā kirurǵijā. Apbalvots ar Sarkanā karoga un Sarkanās zvaigznes ordeni. Darba Varonis 1936. Miris 1942 Piņugā, Kirovas apgabalā.

Vēres: LĀP 17; P 239; PME 579-580; Veselïba. - 1973. - Nr.10. - 27. lpp.

\section{Jēkabs Dille}

Dzim. 24. dec. 1890 Rīgā. Beidza Rīgas Nikolaja ǵimnāziju. Stud. PKMA 1908-14, ārsts. Kara ārsts Kaukāzā un Krimā. Latvijas armijas ārsts, pēcāk slimokasu uzticības ārsts un internists Rīgā. LPSR Veselības aizsardzības tautas komisariāta ierēdnis 1940 41. Represēts 1941-57. Ārsts Vēršu ambulancē Rūjienas raj. Miris 1960 Rūjienā, apb. Meža kapos Rīgā.

Vēres: A 45; LMP; P 227-228; Latvijas Ārsts. - 1996. - Nr. 2. 149. Ipp.

\section{Gedimins Ebels}

Dzim. 4. dec. 1895 Cēsu apr. Beidza PKMA 1919 un LU 1923. Ārsts Džūkstē, no 1927 Rīgā. Rep. bērnu klīn. slimnīcas ārsts 1948-57. LVU Bērnu slimību kat. vad. 1947-49. Dib. Latvijas Pediatru zin. biedrību 1948. Pētīja bērnu tuberkulozi. Miris 8. nov. 1967 Rīgā, apb. Meža kapos.

Vēres: P 232; PME 582; V 90; Medicīna. Vēsture. Valoda. - Rīga, 1993. - 15. lpp.

\section{Ernsts Fērmanis}

Dzim. 3. martā 1872 Pēterburgā mācītāja gimenē, vācietis. Beidza Pētera ǵimnāziju Pēterburgā. Stud. TU 1890-91, PKMA 189196, ārsts. Kara ārsts 1897-1900. Ārsts un pētnieks Pēterburgā 1900-14. PKMA Dr.med. 1907, disertācija "Smertnost ot brušnogo tifa za let s 1896-1907 g. v S.Peterburge”. Kara ārsts 1914-18. TU docētājs 1920-21. LU docētājs 1921-39, Higiēnas kat. vad. 1921-39, profesors 1927. Pētnieks Pozenē (Poznañā) 
1940-43. Pētījumi higiēnā. Miris 7. okt. 1947 Holšteinā, Vācijā.

Darbi: Higiēna. - Rīga, 1928; $1937^{2}$.

Vẽres: EVP 164; LĀP 23; LUX 459-461; LUXX 411; LVVA 7427. f., 13. apr., 476. 1.

\section{Eduards Gartjē}

Dzim. 27. aug. 1872 Pēterburgā tirgotāja ğim., francūzis (? Igaunijas pavalstnieks). Beidza Pētera gimnāziju Pēterburgā, PKMA 1896. Ārsts Pēterburgā, PKMA docētājs 1898-1914. PKMA Dr.med. 1900, disertācija "Cilvēka augla un jaunpiedzimušā aizkunğa dziedzeris" (krievu val.). Petrogradas Psihoneirologiskā institūta profesors no 1914. LU Bērnu slimību kat. vad. 1921-44. Pētijumi pediatrijā. Vēlāk Vācijā un Skotijā. Miris 4. dec. 1959 Edinburgā, apb. Nevingtona kapos.

Vēres: EVP 177; LĀP 24; LUXX 411-412; LVVA 7427. f., 13. apr., 527. 1.; Medicīna. Vēsture. Valoda. - Rīga, 1993. -25.-26. lpp.

\section{Voldemārs Gludiṇ̌}

Dzim. 25. jūn. 1889 Vainodes pag. zemnieka gim. Beidza Liepājas ǵimnāziju 1910. Stud. Pēterburgas U farmāciju 1911-12, TU 1914, PKMA 1914-18, ārsts. Ārsts Sibīrijā un Kolčaka armijā 1918-21. Ārsts Durbē no 1921, arī pilsētas galva. Miris 24. jūl. 1938.

Vēres: MĀ; P 233.

\section{Nikolajs Grundulis}

Dzim. 1873. Stud. PKMA 1896-1901. Kara ārsts Plockā un Lodzā, pulkvedis.

Vēres: LĀS; M 45; RMS 1905, 1914.

\section{Rihards Hjords}

Dzim. 8. martā 1884 Rịgā, namsaimnieka ǵim., dānis. Beidza Aleksandra ǵimnāziju Rīgā. Stud. PKMA 1906-12, ārsts. Dienēja kājnieku dạās, demobilizēts 1918 un tūlīt mobilizēts Sarkanarmijā. Latvijas armijas Vidzemes artilērijas pulka vec. ārsts 1920-39, pulkvežleitnants. Pēcāk Vācijā. Miris 22. janv. 1945 Karcigā, Rietumprūsijā. Apbalvots ar Triju Zvaigžṇu ordeña 4. 
šḳiru, Atzinības krusta 3. šķiru, 3 Krievijas ordeniem.

Vēres: LAAV 198.

\section{Pēteris Jākobsons}

Dzim. 23. sept. 1900 Pēterburgā (pēc citiem datiem - Liepājā) strādnieka ǵim. Beidza PKMA 1924 (liekas, iestājies pēc 1918). Sarkanarmijas ārsts Tālos Austrumos, vēlāk Ľenningradā, pēc 1944 Daugavpilī un Rīgā. RMI Ādas un venērisko slimību kat. vad. 1953-72, profesors 1966. Med. zin. kand. 1954, dokt. 1965. Latvijas Dermatovenerologu zin. biedrïbas priekšsēdētājs 195372. Pētījumi mikologijā, ādas slimību kūrortdziedniecībā, trihomoniāzes diagnostikā. Apbalvots ar Darba sarkanā karoga ordeni. LPSR Nop. bag. ārsts 1950. Miris 29. dec. 1974 Rịgā, apb. Meža kapos.

Darbi: Ādas sēnīšu slimỉbas. - Rīga, 1954.

Vēres: PME 587; V 91; Medicīna. Vēsture. Valoda. - Rīga, 1993. - 47. lpp.; Pad. Mediķis. - 1975. - 9. janv.

\section{Kirils Jankovičs}

Dzim. 1. jūl. 1858 Zaubes pag. zemnieka gim. Beidza Rīgas garīgo semināru. Stud. Pēterburgas U matemātiku 1882-84, PKMA 1884-88. Ārsts Pēterburgā un Carskoje Selo. Ārsts Ainažos, Zaubē, Rīgas kara slimnīcā. Miris 24. martā 1939 Zaubē.

Vēres: LĀS; LMP 1939; M 48; RMS 1914; Universitas, 1939. - Nr. 6. 155. Ipp.

\section{Jānis Jankovskis}

Dzim. 6. febr. 1876 Poislīcē, Kauñas gub. Beidza Rīgas pils. gimnāziju 1897. Stud. Kijevas U 1897-99, Berlīnes U 1899-1902, Dr.med. 1902, disertācija "Über Pseudoleukaemie und Anaemia splennica". PKMA ordinators 1902-03. Krievijas un Japānas kara dalībnieks. Rīgas 1. slimnīcas ārsts 1905-14. TU Dr.med. 1910, disertācija " $K$ voprosu o kolotorezannih $i$ ognestrelnih pronikajuščih povreždeniah brušnoi polosti”. Kara ārsts latviešu strēlnieku da|āās 1914-18. LU Hospitālās ḳirurgijas klīnikas vad. no 1920, profesors 1924. Latvijas Sarkanā Krusta dib. un priekšnieks 
no 1918. Pētījumi kara ķirurǵijā, kaulu tbc kirurǵiskā ārstēšanā, barības vada plastikā. Miris 6. dec. 1925 Rīgā, apb. Meža kapos, kapa pieminekla autors K. Jansons 1927. 1931-40 J. Jankovska vārdā saukta Sarkanā Krusta sanatorija Liepājā.

Vëres: LUXX 412-414; LVVA 7427. f., 13. apr., 675. 1.; PĀT 84-85; PME 587; V 91.

\section{Jānis Jēgermanis}

Dzim. 15. martā 1895 Rīgā dārznieka ǵim. (pirmais uzvārds Blese). Beidza Aleksandra ġimnāziju Rīgā 1914. Stud. PKMA 1914-19, Sarkanarmijas ārsts 1919-21, beidza LU 1923. LU docētājs 1923-28. Rīgas 1. slimnīcas ārsts un nod. vad. no 1928. Pētījumi praktiskā kirurǵijā. Apbalvots ar Ľeņina ordeni 1966. LPSR Nop. bag. ārsts 1947. PSRS Augstākās padomes deputāts 1954-62. Miris 14. jūn. 1968, apbed. Meža kapos, kapa pieminekla autore L. Rezevska 1969. Piemiņas plāksne Rīgas 1. slimnīcas 10. nodaḷā, tēlnieks J. Strupulis 1990.

Vēres: LVVA 7427. f., 13. apr., 698. 1; P 233; PĀT 130-131; PME 588; V 84, 92; Glāzis T., Sluckers D. Jānis Jēgermanis. - Rīga, 1974.

\section{Kārlis Eduards Kalniṇš}

Dzim. 6. dec. 1884 Vitebskas gub. Stud. PKMA 1904-11. Kara ārsts Aizbaikālā.

Vēres: LĀS; M 115; RMS 1914.

\section{Krišjānis Kalniņš}

Dzim. 22. dec. 1864 Rūjienas pag. zemnieka ǵim. Beidza Tērbatas reālskolu, Pēterburgas U dabaszinību fak. 1888, PKMA 1893. Krievijas armijas un flotes ārsts 1894-1918, pulkvedis. Krievijas un Japānas kara dalībnieks, Amūras flotiles vec. ārsts 1910-18. Japānas dienestā 1918-19. Kolčaka armijas ārsts 191920. Latvijas armijas aviācijas parka un arsenāla ārsts 1920-27. Vēlāk terapeits un pediatrs Rīgā. Apbalvots ar vairākiem Krievijas ordeņiem, Francijas Goda leǵiona kavaliera krustu, Japānas Sv. Draguna ordeña 5. šḳiru. Miris 31. martā 1945 Rīgā.

Vēres: İ 21; LAAV 227-228; LĀS; LMP 1943. 


\section{Jermolajs Kanskis}

Dzim. 7. dec. 1872 Dubultos skolotāja gim., krievs. Beidza ġimnāziju Varšavā, PKMA 1896. Turpat ordinators otorinolaringologijā 1897-1903, Dr.med. Tveras gub. vec. ārsts 1903-05, Olonecas un Samaras gub. med. inspektors 1905-17, Taškentas dzelzcela valdes konsultants 1914-17. Kolčaka armijas pulka vec. ārsts, kara sanitārais inspektors 1919-20, pulkvedis. Ārsts Ilūkstē 1921-23. Latvijas armijas Daugavpils kara slimnīcas ordinators 1923-26, 10. Aizputes kājnieku pulka vec. ārsts 1926-28. Vēlāk kirurgs un otorinolaringologs Rīgā. Miris 4. febr. 1946 Rīgā.

Vēres: İ 21; JP; LAAV 236-237.

\section{Andrejs Kaṇepājs}

Dzim. 1895. Stud. PKMA no 1914, ārsts. Rīgas Sarkanā Krusta slimnīcas rentgenologs no 1922. Miris 20. jūl. 1924.

Vēres: MĀं; P 232.

\section{Jānis Kārkliṇš}

Dzim. 1896 Jaunburtnieku pag. Beidza Rīgas Nikolaja ǵimnāziju 1916. Stud. PKMA 1916-18, LU 1921-23, ārsts. Ärsts Straupē 1924-64. Miris 1966, apb. Rìgas Meža kapos.

Vēres: LMP 1939; P 237.

\section{Dāvids Kessels}

Dzim. 15. sept. 1892 Rīgā. Beidza Nikolaja ġimnāziju Rīgā 1912. Stud. PKMA un Kijevas U, ārsts 1917. Latviešu strēlnieku ārsts 1917-19. Ārsts Limbažos 1921-37. Preilu slimnīcas direktors 1937-41. Ginekologs Rīgā 1941-44. Pēcāk Vācijā un no 1951 ASV, psihiatrs. Miris 25. jūl. 1955 Minesotā.

Vēres: LĀP 32; LĀZA Apkārtraksts. - 1955. - Nr. 42.

\section{Vasilijs Klimenko}

Dzim. 1. apr. 1868 Odesā, krievs. Beidza PKMA 1893, Dr.med. 1895, disertācija "Opiti issledovania raspostranenia glist $v$ Finlandii". Kara ārsts 1893-1900, pēc tam papildinājās Cīrihē, Parīzē, Bernē. Krievijas un Japānas kara dalībnieks. Pēterburgas 
Eksperimentālās medicīnas institūta asistents 1905-19, profesors 1919. Samaras U profesors 1919-21. LU Iekšḳīgo slimību propedeitikas un diagnostikas kat. vad. 1921-38. Pētijis garo klepu u.c. infekcijas slimības. Miris 19. okt. 1941 Rīgā.

Vēres: LUX 563-564; P 239; PME 591.

\section{Jēkabs Knostenbergs}

Dzim. 30. aug. 1893 Blomes pag. zemnieka gim. Beidza Rìgas pils. gimnāziju 1914. Stud. PKMA ar pārtraukumiem 1914-19, beidza LU 1924. Latvijas armijas ārsts 1925-27. Ārsts Velēnā 1927-31, Rīgā 1931-44. Pēcāk Vācijā, no 1949 Austrālijā, ostas strādnieks Adelaidē. Miris pēc 1974.

Vēres: LĀP 33; P 233-234.

\section{Juris Kraulis}

Dzim. 15. maijā 1882 Kurzemē, Rimzātciemā. Mācījās Kuldīgas skolotāju seminārā, beidza Carskoje Selo gimnāziju 1903. Stud. dabaszinības Pēterburgas U 1904-08, Cand.rer.nat. Stud. PKMA 1908-12, TU 1912-16, ārsts. Kara ārsts Daugavpils hospitālī 1914-17. Kuldīgas aprinkka ārsts 1919-34. Ārsts Kuldīgā 193541. Represēts 1941. Miris ap 1960 Dušanbē.

Vēres: A 48; BK 256; P 223; Veselỉba. - 1990. - Nr. 7. - 16.-17. Ipp.; Nr. 8. - 16.-17. lpp.

\section{Kārlis Morics Lejiṇš}

Dzim. 29. nov. 1858 Vecates pag. zemnieka gim. Beidza Aleksandra gimnāziju Rīgā. Stud. Pēterburgas U dabaszinības 1881-84, PKMA 1884-88, ārsts. Kara ārsts Viḷnā 1889-94. Ārsts Rīgā no 1894, fizikālterapeitiskā kabineta îpašnieks, pirmais latviešu rentgenologs. LĀB priekšnieks 1902-03. Miris 1919. LPSR ZA pirmā prezidenta P. Lejiña vecākais brālis.

Vēres: BK 266; M 61; Paulis Lejiņš dzīvē un darbā. - Rīga, 1983. 11. lpp.

\section{Jānis Lībietis}

Dzim. 11. dec. 1885 Brengulu pag. zemnieka gim. Beidza Tērbatas reālskolu 1905. Stud. PKMA 1905-11, ārsts. Dienēja Polijā, Pirmā pasaules kara dalībnieks, arī latviešu strēlnieku 
dạ̄ās. Latvijas un Igaunijas robežkomisijas loceklis. Valkas slimnīcas direktors 1920-28. Kemeru kūrvietas direktors 192840, 1941-44, uzcēla Kemeru viesnīcu 1936. Apbalvots ar Triju Zvaigžņu ordeņa 4. un 3. šḳiru. Miris 6. nov. 1946 Stokholmā. Viṇa vārdā 1988 nosaukta aleja Ķemeros, 1992 atklāts piemiņas akmens.

Vēres: EVP 307; LĀP 38; P 226; V 78, 87; Latvijas Ārsts. - 1992. - Nr. 3. -321 . lpp.

\section{Justīns Liepa}

Dzim. 14. sept. 1889 Skaistkalnes pag. Stud. PKMA 1913-15, TU 1915-18, beidza LU 1921. Ārsts Liepājā 1921-23, pēcāk Rīgā, 4. slimnīcas terapeits. LPSR Nop. bag. ārsts 1958. Miris 28. aug. 1962 Rīgā, apb. Meža kapos, kapa pieminekļa autore L. Rezevska 1976.

Vēres: Š 1149; V 94.

\section{Aleksandrs Liepiňs}

Dzim. 25. apr. 1874 Rīgā. Beidza gimnāziju Rīgā. Stud. PKMA 1892-97, ārsts. Kara ārsts Rīgā un Krievijas un Japānas karā 1897-1905. Dzelzceḷa ārsts Aizbaikālā 1904-17. Ārsts Čitā 1917-27. Dzelzceḷa ārsts Rīgā no 1927. Miris 28. nov. 1939 Rīgā.

Vēres: M 60; RMS 1914; Ārsts. - 1939. - Nr. 1. - 65. lpp.

\section{Augusts Lietavietis}

Dzim. 18. febr. 1893 Bērzaunes pag. zemnieka gim. Beidza Pleskavas ǵimnāziju 1912. Stud. PKMA 1912-13, beidza Maskavas U 1917. Pētnieks Maskavā, PSRS MZA Darba higiēnas un arodslimibu inst. laboratorijas vad. no 1935, inst. direktors 1948 71. Med. zin. dokt. 1935, profesors 1935. Centrālā Ārstu kvalifikācijas celšanas inst. kat. vad. 1931-55. PSRS MZA akadēmiḳis 1950. Starptautiskās arodslimību organizācijas viceprezidents 1961-72. Pētījumi darba higiēnā un fiziologijā, med. radiologijā. Alpīnists, viņa vadītā ekspedīcija 1937 atklāja un 1938 sasniedza Uzvaras smaili Tjanšanā. Apbalvots ar 3 Ľennina ordeniem 1943, 1963, 1971, citiem ordeñiem. Ľen̦ina prēmijas (slepenās) 1963, Sta|̧ina prēmijas laureāts 1949. PSRS Nop. bag. sporta meistars 
1946. Miris 29. jūn. 1984 Maskavā. Viṇa vārdā nosaukta virsotne Tjanšanā un kalnu pāreja Pamirā.

Vēres: PME 595; Simonov J. Pik Letaveta. - M., 1974.

\section{Jānis Manass}

Dzim. 13. jūn. 1883 Ropažu pag. Beidza Rīgas Aleksandra ġimnāziju 1902. Stud. TU 1902-07, PKMA 1907-11, ārsts. Kara ārsts Habarovskā 1910-14. Ārsts Sibīrijas strēlnieku da|ās 191418, turpmāk Denikina armijā un 1920 Sarkanarmijā. Latvijas armijā 3. robežsargu pulka vec. ārsts 1920-22, 3. Jelgavas kājnieku pulka vec. ārsts 1922-40, pulkvežleitnants. Arī pediatrs Jelgavā līdz 1944, pēcāk Vācijā un Austrālijā. Apbalvots ar Triju Zvaigžņu ordeṇa 4. škiru, Atzinības krusta 3. šķiru, 4 Krievijas ordeṇiem. Miris 22. febr. 1966 Sidnejā.

Vēres: BK 288; LAAV 319; LĀP 40; LMP 1943.

\section{Jānis Martinsons}

Dzim. 24. sept. 1859. Beidza PKMA 1883. Dr.med. 1888. Ārsts Liepājā 1896-97, kara ārsts Minskā, Bobruiskā, Vladikaukāzā, pulkvedis.

Vēres: LĀS; M 64; RMS 1914.

\section{Aleksandrs Mežaks}

Dzim. 3. jūn. 1863 Vestienas pag. dzirnavnieka gim. Stud. PKMA 1881-82, TU 1882-88, ārsts. Ārsts Veselaukā 1896-98. Miris pirms 1904.

Vēres: BL 286; LĀS; M 66; Š 262

\section{Pāvils Mucenieks}

Dzim. 27. sept. 1891 Plaviñās rokpelṇa ǵim. Beidza Rīgas Aleksandra gimnāziju 1913. Stud. PKMA 1913-17, ārsts. Ārsts latviešu strēlnieku pulkos, Alūksnē, Rēzeknē. Rīgas 1. slimnīcas ārsts no 1921, nod. vad. no 1928. LU Dr.med. 1925, disertācija "Eksperimentāli pētījumi par žultsvadu plastiku". LU docētājs no 1921, Fakultātes kirurǵijas kat. vad. un ārkārtas profesors 1940. Pētījumi vēderdobuma, plaušu, plastiskā un neirokirurǵijā. Miris 7. maijā 1940 Rīgā, apb. Varak|ānu kapos, kapliča pēc A. Bērziṇa 
projekta 1937 ("Birst ābelei balti ziedi").

Vērs: LVVA 7427. f., 13. apr., 1178. 1.; P 231-232; PĀT 112-113; PME 599; V 94.

\section{Voldemārs Ozols}

Dzim. 9. aug. 1887 Rīgā strādnieka gim. Beidza Nikolaja gimnāziju Rīgā 1908. Stud. PKMA 1908-14, ārsts. Dienēja Kaukāzā. Latvijas armijā 1920-22. Ārsts Rīgā. Apbalvots ar Krievijas ordeñiem. Miris 1.dec. 1943 Rīgā.

Vēres: LMP 1921, 1928; P 228; Ārstniecības Žurnāls. - 1943. - Nr. 7. 477. Ipp.

\section{Jānis Paegle}

Dzim. 17. apr. 1888 Dignājas pag. zemnieka gím. Beidza PKMA 1914. Dienēja kājnieku dạ̄ās 1914-18, Deṇikina armijas ārsts 1918-19. Latvijā atgriezās 1921. Latvijas armijas Kurzemes artilērijas pulka vec. ārsts 1926-29, 1936-40, Liepājas kara slimnīcas vec. ordinators 1929-36, pulkvežleitnants. Sarkanarmijas ārsts 1940-41. Izglāba no uzspridzināšanas 1944 Asaru dzelzceḷa staciju. Vēlāk Dubultu poliklīnikas ārsts un Rīgas Jūrmalas galv. ārsts. Apbalvots ar Atzinības krusta 4. škiru un 2 Krievijas ordeniem. Miris 19. janv. 1949.

Vēres: LAAV 354; Sov. Latvija. - 1960. - 17 avg.

\section{Kirils Plaude}

Dzim. 1888. Beidza PKMA 1914. Pediatrs Rīgas Dž. Ārmitsteda bērnu slimnīcā. Miris 8. jūl. 1959 Rīgā.

Vēres: LMP 1921, 1939.

\section{Jēkabs Prīmanis}

Dzim. 12. martā 1892 Ādažu pag. zemnieka ǵim. Beidza Nikolaja gimnāziju Rīgā 1911. Stud. TU 1911-13, PKMA 1913-18. Ārsts Baltijas flotē, Orlā, Ādažos, Rīgā. LU docētājs 1920-44, Anatomijas kat. vad. 1929-44, Med. fak. dekāns 1939-40, 194143, profesors 1932. LU Dr.med. 1926, disertācija "Ductus cochlearis ārējās sienas attīstība un uzbūve". Rokfellera fonda stipendiāts 1925-26. Veselības veicināšanas biedrības Tautas dzīvā spēka pētǐšanas inst. vad. 1938-40. Baltijas U profesors 
1946-48. Pitsburgas U profesors 1948-62. Pētijumi anatomijā un latviešu antropologijā. Apbalvots ar Triju Zvaigžņu ordeņa 3. škiru, Atzinības krustu un ASV studentu balvu "Zelta ābols" 3 reizes. Kr. Barona prēmija 1930. Miris 22. nov. 1971 Pitsburgā. Viṇa vārdā neoficiāli nosaukta P. Stradiṇa Medicīnas vēstures muzeja filiāle - Jēkaba Prīmaṇa Anatomijas muzejs. Jēkaba Prīmaņa balva kopš 1999 .

Darbi: Latviešu anatomiskā vārdnīca. - Rīga, 1931.

Vēres: LĀP 48; LVVA 7427. f., 13. apr., 1367. 1.; LUXX 420-422; P 230-231; PĀT 116-117; Lindberga $R$. Museum anatomiae Jacobi Primani. - Rīga, 1995.

\section{Eduards Pumpurs}

Dzim. 18. apr. 1894 Dzelzavas pag. mūrnieka ǵim. Beidza Aleksandra ǵimnāziju Rīgā 1915. Stud. PKMA 1915-21, ārsts. Turpat ordinators 1921-23. Beidza LU 1924. Latvijas armijas ārsts un vec. ārsts 2. Ventspils, 1. Liepājas kājnieku pulkā, Kurzemes artilērijas pulkā, jātnieku pulkā 1925-31, vec. ārsts 5. Cēsu kājnieku pulkā, smagās artilērijas pulkā un sapieru pulkā 1931-40, pulkvežleitnants. Arī ginekologs Rīgā. Sarkanarmijas ārsts 1940-41. Represēts 1941-54. Ārsts Spārē Cēsu raj. Apbalvots ar Atzinības Krusta 4. šḳiru. Miris 6. apr. 1960 Rīgā, apb. Meža kapos.

Vēres: LAAV 382; LMP 1940; P 234.

\section{Jēkabs Romans}

Dzim. 8. febr. 1886 Salgales pag. zemnieka gim. Beidza Jelgavas gimnāziju 1905. Stud. PKMA 1905-12. Kara ārsts Tālos Austrumos u.c. līdz 1922. Rīgas 1.slimnīcas nod. vad. no 1923. LVU un RMI docētājs 1944-52. Pētījumi rentgenoloǵijā. LPSR Nop. bag. ārsts 1947. Miris 13. febr. 1953 Rīgā, apb. Meža kapos.

Vēres: EVP 417; LĀS; P 226; PME 604; V 97; Veselība. - 1986. - Nr. 5. - 13.-14. Ipp.

\section{Kristaps Rudzītis}

Dzim. 23. apr. 1899 Tadaiķu pag. skolotāja ğim. Beidza Liepājas Nikolaja ġimnāziju 1917. Stud. PKMA 1917-22, ārsts. Pēc atgriešanās Latvijā beidza LU 1923. Turpat docētājs, 1929-30 
papildinājās Ķ̄̄lē. LU Dr.med. 1932, disertācija "Klīniski un koloīdḳimiski pētījumi par paradoksām reakcijām". LU Propedeitiskās klīnikas un Diagnostikas kat. vad. 1938-44, profesors 1940. Talsu slimnīcas direktors 1944-45. LVU un RMI Fakultātes terapijas kat. vad. 1945-72, sākotnēji kā med. zin. kand. un docents, 1959 atjaunots med. zin. dokt. un profesors. Paralēli strādāja Latvijas Eksperimentālās un klīniskās med. inst. un RMI Saistaudu fiziologijas un patologijas laboratorijā, ko dib. 1961. Latvijas Terapeitu zin. biedrỉbas priekšsēdētājs 1958-73. Pētījumi saistaudu fiziologijā un patologijā, fokālās infekcijas nozīme slimību ġenēzē, kolīdķīmisko reakciju, meteorologisko u.c. faktoru izraisītās pārmaiñas cilvēka organismā, med. terminologijā. LPSR Nop. bag. zin. darbinieks 1959. Miris 27. febr. 1978 Rīgā, apb. Meža kapos. Piemiṇas plāksne 1992 Rīgā, Āgenskalna ielā 11. Kristapa Rudzīša aleja 1988 K̦emeros. Kristapa Rudziša balva kopš 1999.

Darbi: Iekškīigo slimību vispārējā diagnostika. - Rīga, 1949; 1960²; Diagnostikas pamati un terapijas preambula. - Rīga, 1972; Terminologia medica: vol. 1-2. - Rīga, 1973, 1977; Geparinociti v klinike i eksperimente. - Riga, 1959.

Vēres: EVP 425-426; LMA arhīvs 7. apr., 827., 2824. 1.; LUXX 430431; LVVA 7427. f., 13. apr., 1516. 1.; P 237-238; PĀT 142-143; PME $605 ; \mathrm{V} 85,87,97$.

\section{Antons Skrinda}

Dzim. 15. okt. 1885 Līksnas pag. zemnieka gim. Beidza Pēterburgas 8. gimnāziju 1902. Stud. PKMA 1902-05, Bernes U 190506, PKMA 1906-09, ārsts. Kara ārsts Kanskā 1910-12, ārsts N̦ižṇeudinskā 1912-13, Rēzeknē 1913-14. Kara ārsts frontē 191417, gūstā 1917-18. Latgaliešu rakstnieks Ontons Skrynda, pseidonīmi Leidumnīks, Celaveirs. Redaktors, publicists, kultūras darbinieks, izdevis vairākus krājumus. Miris 31. martā 1918 Rēzeknē, apb. Miera ielas kapos, kapa pieminekla autors B. Buls 1975. Piemiņas akmens un krusts brāliem Skrindām 1990 Vaboles pag. pie Liepas Mukāniem. Brālu Skrindu iela Rēzeknē, 1989 atjaunots pirmskara nosaukums. Brālu Skrindu Atašienes vidusskola.

Vēres: LĀS; M 128; PME 606; V 50, 79, 87, 97; Latviešu literatūras darbinieki. - Rīga, 1965. - 270.-271. lpp. 


\section{Pēteris Snikers}

Dzim. 7. dec. 1875 Skultes pag. zemnieka gim. Beidza Rīgas Nikolaja gimnāziju 1896. Stud. PKMA 1896-1901, ārsts. Strādāja PKMA klīnikā 1901-04, Dr.med. 1904, disertācija “ $K$ voprosu o suščnosti Lichenis scrofulosorum". Tajā pirmoreiz pasaulē konstatēta tuberkulīna ādas reakcija. Rīgas kara hospitāla ordinators un nod.priekšnieks 1905-14. Ārsts frontē, arī latviešu strēlnieku vienībās 1914-18. Tērbatas U privātdocents 1916-18. Latvijas armijas Kara sanitārās pārvaldes pirmais priekšnieks 1919-33, pirmais ārsts generālis 1923. LU Med. fak. līdzdibinātājs 1919, Ādas un venerisko slimỉbu kat. vad. no 1922, Med. fak. dekāns 1933-35, 1937-39, profesors 1923. Daudzkārt komandēts uz ārzemēm. Latvijas Baltā Krusta biedrības dib. un priekšnieks 1921-37 (40). Latvijas Dermatovenerologu biedrïbas dib. un priekšnieks 1924-40. LĀB priekšnieks 1932-38. Pētījumi sifilisa terapijā un diagnostikā, venerisko slimību profilaksē, kara medicīnā. Mākslas darbu kolekcionārs. Apbalvots ar Triju Zvaigžnuu ordenna 3. un 2. škiru, 5 Krievijas ordeniem, Lietuvas Gedimina ordeña 2. šķiru, Polijas Atdzimšanas ordeņa 3. škiru u.c. Miris 5. dec. 1944 Rīgā, apb. Meža kapos. Piemiṇas plāksne 1993 pie nama Rīgā, Brīvības ielā 39 .

Darbi: Lipīgas slimības. - Rīga, 1915; Karš un veneriskas slimỉbas. Limbaži, 1917; Laulỉba un dzimuma slimỉbas. - Rīga, 1920; Kā izsargăties no veneriskām slimībām. - Rīga, 1923.

Vēres: EVP 450; İ; LAAV 428-429; LUXX 423-425; LVVA 7427. f., 13. apr., 1611. 1.; 5601. f., 1. apr., 5923. 1.; P 226-227; PĀT 82-83; PME 607; Iz istorii medicini. - Riga, 1962. - T. 4. - S. 87-93; Riga, 1987, - T. 17. - S. 86-96; Latvijas Ärsts. - 1990. - Nr. 3. - 63.-65. Ipp.; Miltiņš A. Pēteris Snikers: Dzīve un darbība. - Rīga, 1993.

\section{Reinholds Voldemārs Sniḳers}

Dzim. 6. dec. 1893 Skultes pag. zemnieka gim., P. Sniķera jaunākais brālis. Beidza Rīgas Nikolaja gimnāziju 1911. Stud. PKMA 1911-18. Kara ārsts latviešu strēlnieku vienībās, 1919-20 Sarkanarmijā. Ārsts Rīgas slimnīcās, papildinājās ārzemēs. LU Dr.med. 1930, disertācija "Deniņu kaula pneimatizācija un tã vaiga sastrutojums vidusauss iekaisuma gadījumos". LU docētājs 
1926-44, Ausu, kakla un deguna slimỉbu kat. dib. un vad. 1935-44, profesors 1938. Ārsts Austrijā 1944-49. Psihiatrs ASV 1949-53. Pētijumi otorinolaringoloǵijā un pediatrijā. Miris 6. nov. 1953 Čikāgā.

Vēres: EVP 451; LĀP 54; LUXX 425-426; LVVA 7427. f., 13. apr., 1612. 1.; P 229; Medicīna. Vēsture. Valoda. - Rīga, 1993. - 32. lpp.

\section{Pēteris Spalvin̄š}

Dzim. 1870. Beidza PKMA 1894. PKMA Dr.med. 1904, disertācija " $K$ voprosu ob izmeneniah gazoobmena $u$ životnih pod vlianiem različnih jadov". Kara ārsts Tālos Austrumos, Daugavgrīvā. Pēcāk dermatovenerologs Rīgā. Miris pēc 1944.

Vēres: LMP 1921, 1928, 1943; RMS 1905, 1914.

\section{Pauls Stradin̄š}

Dzim. 17. janv. 1896 Viesītes pag. amatnieka ǵim. Beidza Rīgas Aleksandra ġimnāziju 1914. Stud. PKMA 1914-19, ārsts. Strādāja PKMA klīnikā 1919-23, Dr.med. 1923, disertācija "Povreždenia periferičeskih nervov $i$ ih lečenie". LU un RMI docētājs no 1924, kat. vad. no 1928, Med. fak. dekāns 1944-46, profesors 1933. Daudzkārt komandēts uz ārzemēm. LU Dr.med. 1928, disertācija "Par tā saucamās gangraena spontanea etiologíiju, klīniku un terapiju". Rīgas 2., resp. Republikas klīniskās slimnīcas med. direktors un galv. ārsts 1931-41, 1944-47. Dib. Vēža slimnīcu 1939, Republikas asinspārliešanas staciju 1941, Rīgas 2. med. skolu 1939. LPSR ZA Bioloǵijas un eksperimentālās med. inst. direktors 1946-51, Latvijas Eksperimentālās un klīniskās med. inst. sektora vad. no 1951. LPSR Veselības aizsardzības ministrijas Med. zin. padomes priekšsēdētājs 1941, 1944-48, galv. kirurgs 1945-49. Dib. un vad. Vēža apkarošanas biedrību 1934-37, Veselības veicināšanas biedrību 1937-40, LPSR Ārstu biedrïbu 1945-46, LPSR Kirurgu zin. biedrību 1946-52, Latvijas Med. vēsturnieku zin. biedrību 1953, Latvijas Onkologu zin. biedrību no 1954. Izveidojis Med. vēstures muzeju 1944. Pētījumi perifēro nervu ķirurgijā, vēža agrīnā diagnostikā, Latvijas medicīnas vēsturē un citi. LPSR ZA akadēmikikis 1946, PSRS 
MZA korespondētājloceklis 1945. LPSR Nop. bag. zin. darbinieks 1945. LPSR Augstākās padomes deputāts no 1955. Apbalvots ar Atzinības krusta 3. šķiru 1939, Darba sarkanā karoga ordeni 1956. Miris 14. aug. 1958 Rīgā, apb. Meža kapos, kapa pieminek]a autors A. Starkopfs 1960. P. Stradiṇa vārdā nosaukts Medicīnas vēstures muzejs 1958, Republikas klīniskā slimnīca 1958, Rīgas 2. med. skola 1989, ielas Ventspilī 1958, Jūrmalā 1986, Viesītē 1987, LMA auditorija 1975. Pieminekḷi Rīgā 1963, tēlniece A. Briede; Viesītē 1987, tēlnieks K. Jansons. Pieminnas akmens 1978 Viesītē, plāksnes 1981 Rīgā pie nama Ventspils ielā 19, Jūrmalā 1986 pie nama Meža prospektā 50, Viesītē 1986 pie nama Rīgas ielā 14. P. Stradiṇa lasījumi kopš 1960, Paula Stradiṇa balva kopš 1983. Pastmarka 1996. Rīgas Stradiṇa universitāte 1998.

Darbi: Izbrannie trudi: t. 1-3. - Riga, 1963-65.

Vēres: P 234-236; Akadēmiķis Pauls Stradin̄š. - Rīga, 1959; Pauls Stradinš dzīiee un darbā. - Rīga, 1961; Vīksna A. Paula Stradiņa dzīves un darba vietas. - Rīga, 1975; Stradinšs. J., Arons K.E. ., Vìksna A. Tāds bija mūsu laiks... - Rīga, 1996.

\section{Pauls Strūve}

Dzim. 20. dec. 1891 Pēterburgā ierēdṇa giim., krievs. Beidza PKMA 1915. Krievijas armijas ārsts 1915-18. Judeniča armijas ārsts 1918-20. Latvijas armijas ārsts Rīgas kara slimnīcā 1920 21, 9. Rēzeknes kājnieku pulka vec. ārsts 1921-40, pulkvežleitnants. Rēzeknes poliklīnikas terapeits 1940-41. Apbalvots ar Triju Zvaigžṇu ordeņa 5. un 4. šḳiru, Aizsargu nopelnu krustu, Krievijas Jura medalas 4. šḳiru un 2 citiem Krievijas orden̨iem. Sarkanarmijai atkāpjoties, nošauts 30. jūn. 1941 Rēzeknē, apb. Upes ielas kapos. Piemiñas plāksne 1991 Rēzeknē pie nama Sporta ielā 41.

Vēres: LAAV 443-444; LMP 1940; V 160, 189, Lauku Avīze. - 1989. 31. marts; Grišāne V. No Rēzeknes medicīnas vēstures. - Rēzekne, 1996. - 98.-104. lpp. 


\section{Eduards Šable}

Dzim. 1890 Bauskas pag. skolotāja gim. Beidza Jelgavas ǵimnāziju 1909. Stud. PKMA 1909-14, ārsts. Kara ārsts 1914-15, gūstā 1915-18. Ārsts Viesītē 1918-25. LU asistents 1925-28. Vēlāk ginekologs Rīgā. Miris pēc 1950.

Vēres: LAAV 11; LMP 1939; LUXX 480; P 238.

\section{Jēkabs Šīrons}

Dzim. 2. janv. 1870 Krapes pag. zemnieka gim. Beidza Rīgas pils. gimnāziju 1890. Stud. TU 1891-96. Kara ārsts 1897-98. Ārsts Balvos 1899-1904. Krievijas un Japānas kara dalībnieks 1904-06. Ārsts Pēterburgā 1907-14, papildinājās ārzemēs. PKMA Dr.med. 1914, disertācija "Ob izmeneniah šķitovidnoi železi u detei sifilitikov". Kara ārsts 1914-17. Rīgas leprozorija direktors 1919-26. LU docētājs 1921-38. Pētījumi leprologijā. Miris 1. janv. 1945 Rīgā, apb. Lielos kapos.

Vēres: EVP 473; LĀS; LUX 495-497; LVVA 7427. f., 13. apr., 1684. 1.; Latvijas Ärsts. - 1992. - Nr. 5. - 525. lpp.; Veselïba. - 1987. - Nr. 9. -26 . Ipp.

\section{Augusts Škipsna}

Dzim. 4. janv. 1886 Jaungulbenes pag. Beidza PKMA 1913. Dienēja kājnieku dạ̄ās un hospitāḷos Varšavā u.c., piedalījās Pirmā pasaules karā 1914-18. Ārsts Jaungulbenē un Rīgā. Latvijas armijas ārsts 1920-21, pulkvežleitnants. Vēlāk terapeits Rīgā. Apbalvots ar 3 Krievijas ordeniem. Miris 2. apr. 1949.

Vēres: LAAV 451; LĀS; LMP 1939; P 225.

\section{Aleksandrs Šmidts (arī Šmits)}

Dzim. 18. martā 1892 Rengges pag. dzirnavnieka ǵim. Beidza Ventspils reālskolu 1911. Stud. PKMA 1912-16, tad jaun. ārsts frontē, beidza 1922. Turpat docētājs 1922-35, līdztekus I. Mečņikova slimnīcā 1927-36. Vissavienības Vitamīnu zin. pētniecỉbas inst. direktors un Leņingradas 2. Med. inst. kat. vad. 1936-45, profesors 1934, med. zin. dokt. 1939 (vai bez disertācijas?). LVU un RMI Biokīimijas kat. vad. 1945-73, Med. fak. dekāns 1946-49, RMI CZPL nod. vad. no 1972. LPSR ZA 
Biologijas un lauksaimniecības nod. akadēmiḳis sekretārs 194552, LPSR ZA Uztura inst. direktors 1946-51, Latvijas Eksperimentālās un klīniskās med. inst. direktors 1951-53. LPSR Veselíbas aizsardzïbas ministrijas Med. zin. padomes priekšsēdētājs no 1948. Latvijas Bioḳīmiķu zin. biedrības priekšsēdētājs no 1950. LPSR ZA akadēmiķis 1946, PSRS MZA korespondētājloceklis 1960. Pētījumi insulīna un askorbīnskābes biokīmijā un ražošanas tehnologijā, cilvēka parenteriālā barošanā. LPSR Nop. bag. zin. darbinieks 1961. Stalina prēmija 1951. LPSR Valsts prēmija 1972. LPSR Augstākās padomes deputāts un priekšsēdētāja vietnieks 1947-55. Apbalvots ar 3 Lennina ordeņiem 1944, 1951, 1971, 3 Darba sarkanā karoga ordeniem u.c. Miris 18. jūn. 1978 Rīgā, apb. Raiṇa kapos, kapa pieminekḷa autors I. Rapikis.

Darbi: Askorbinovaja kislota, jejo priroda i značenie v živom organizme. - M.-L., 1941.

Vēres: P 229; PĀT 118-119; PME 609; Akadēmiķis Aleksandrs Šmidts: Biobibliogrāfija. - Rīga, 1961; Arons K. Akadēmiḳis Aleksandrs Šmidts. - Rīga, 1972.

\section{Voldemārs Treknais}

Dzim. 1877 Vidzemē. Stud. PKMA 1896-1901. Kara flotes ārsts Kronštatē.

Vēres: LĀS; M 96; RMS 1914.

\section{Edgars Vanags}

Dzim. 15. dec. 1892 Kalncempju pag. skolotāja gím. Beidza ġimnāziju Pēterburgā. Stud. PKMA, vēlāk 1913-16 TU, kad mobilizēts par jaun. ārstu un armijā līdz 1918. Beidza TU 1918. Ārsts Stāmerienā un Rīgā. Latvijas armijā no 1919, 6. martā no ugunslīnijas iznesa nāvīgi ievainoto pulkvedi O. Kalpaku. Latvijas armijā līdz 1921 un 1926-38 dažādos posteņos Liepājā, Alūksnē u.c., pulkvežleitnants. Ärsts Secē un Vecmuižā 1921-26. Ārsts Alūksnē un Mārkalnes pag. 1938-41. Represēts 1941-55. Pēcāk Lielbērzes sanatorijas ārsts. Apbalvots ar Lāčplēša kara ordeña 3. šķiru 1925 par varonību pie Airītēm un Batariem 1919. Miris 11. aug. 1956 Rīgā. 
J. Prīmanis min Kārli Vanagu, kas 1919 bijis Alūksnes latviešu garnizona galv. ārsts. Pięaujams, ka Edgars nosaukts par Kārli, jo par to ziṇas atrast neizdevās.

Vēl ir Eduards Vannahs, dzim. 1890, beidza PKMA 1913, kara ārsts Krievijā un PSRS; 1946 bija sanitārārsts Rīgā, varbūt kāds pārvācojies latvietis.

Vēres: BK 403; LAAV 478; LMP 1928, 1939; P 238; RMS 1914; Š 1027; Latvijas Ārsts. - 1995. - Nr. 11. - 39.-40. lpp.; Lāčplēša kara ordena kavalieri. - Rìga, 1995. - 593. lpp.

\section{Kārlis Mikelis Veidemanis}

Dzim. 7. apr. 1895 Rīgā. Beidza Rēveles Nikolaja ǵimnāziju 1915. Stud. PKMA 1915-18. Jaun. kara ārsts Igaunijas un Latvijas armijā 1918-22. Beidza LU 1923. Turpat docētājs, arī tiesu un policijas ārsts Rīgā. LU Dr.med. 1929, disertācija "Asins grupu nozīme paternitātes noskaidrošanā Latvijā un vinu konstance". Vairākkārt komandēts uz ārzemēm. LU Tiesu med. kat. vad. 1937-40, 1941-44, Med. fak. dekāns 1943-44, profesors 1940. Pētijumi tiesu un sociālā medicīnā. Kr. Barona prēmija 1930. Miris 1. apr. 1945 Irlavā, apb. Sātu kapos.

Vēres: EVP 518; LUX 522-523; LUXX 431-433; LVVA 7427. f., 13. apr., 1866. 1.; P 236-237; V 99; Latvijas Ärsts. - 1995. - Nr. 4. - 59. lpp.; Pulss. - 1995. - apr. I.

\section{Eduards Zarinš}

Dzim. 19. nov. 1876 Jaunraunas pag. zemnieka gim. Stud. farmāciju TU 1901-04. Papildinājās Maskavā, Vīsbādenē. PKMA laborants 1907-08, Mag.pharm. 1908, disertācija "O galenovih preparatah iz različnih sortov valeriani". Zin. un pētnieciskā darbā Pēterburgā 1908-18, arī Sieviešu med. inst. docētājs 1916-18, Petrogradas 2. U profesors 1918. Daudz zin. komandējumu. LU profesors 1919-44, Med. fak. dekāns 1919-20, Veterinārmed. fak. dekāns 1919-20, vēlāk sešreiz ievēlēts par K̦īmijas fak. dekānu. Dr.pharm. honoris causa 1929. LU aptiekas vad. 1924-40. Pēc 1944 Vācijā. Pētijis uzturvielu ḳimijas problēmas, Baltijas jūras ūdens kīmisko sastāvu. Apbalvots ar Triju Zvaigžnuu orden̦a 3. un 4. šḳiru, 
Francijas Goda leǵiona kavalieris. Kr. Barona prēmija 1935. Miris 23. jūl. 1947 Lādē, Vācijā.

Darbi: Uztura vielu kīmija. - Rīga, 1930; Dzeramais ūdens, tā izmantošana un novērtēšana. - Rīga, 1932; Alkoholiskie dzērieni un to izmeklěšana. Rīga, 1932; Vitamīni, hormoni, fermenti un to nozīme uzturā. - Rìga, 1938.

Vēres: EVP 544; LĀP 64; LUX 110-114; LUXX 182-183; Latvijas medicīnas augstskola. - Rīga, 1995. - 122.-124. lpp.; Vìksna A. Vecās aptiekas. - Rìga, 1993. - 111. lpp.

\section{Ludvigs Zeltkalns}

Dzim. 20. nov. 1898 Burtnieku pag. Stud. PKMA 1916-17, beidza LU 1926. Ārsts Pēterupē, Burtniekos līdz 1944. Pēcāk Vācijā, no 1951 ASV. 1997 dzīvoja Kalamazū.

Vēres: LĀP 64.

\section{Kārlis Zentelis}

Dzim. 5, jūn. 1883 Rīgā. Stud. PKMA 1906-?, TU 1912-18, ārsts. Sanitārārsts un internists Rīgā. Apbalvots ar Triju Zvaigžṇu ordeṇa 5. škiru. Miris 27. martā 1936.

Vēres: MĀ; P 224; Š 1012.

\section{Kārlis Zuments}

Dzim. 1861 Rūjienā. Beidza gub. ġimnāziju Rīgā, PKMA 1895, ārsts, Dr.med. 1898. Kara ārsts Varšavā, K̦īnā, piedalījās Krievijas un Japānas un Pirmā pasaules karā. Sanitārārsts Minskā. Karantīnas ārsts Rēzeknē. Vēlāk dermatovenerologs Rīgā. Miris ap 1944.

Vēres: LMP 1940, 1943; M 95.

\section{Apkopojums}

Nav minēti J. Prīmana apcerējumā

A. Balodis; Hermanis Bērzinš̌; J. Biezais; J. Bullis; J. Bune; (R. Hjords);

P. Jākobsons; K. Jankovičš; Krišjānis Kalniňš; (J. Kanskis); D. Kessels; J. Liepa; A. Lietavietis; A. Mežaks; J. Paegle; K. Plaude; P. Spalvị̌s; (P. Strūve); (E. Zariňš); L.Zeltkalns. 


\section{Cittautieši}

E. Fērmanis; E. Gartjē; R. Hjords; J. Kanskis; V. Klimenko; P. Strūve.

Studējuši PKMA, beiguši citur

F. Andreika; J. Bullis; D. Kessels; J. Kārkliňš; J. Knostenbergs; J. Kraulis;

J. Liepa; A. Lietavietis; A. Mežaks; K. M. Veidemanis; L.Zeltkalns; K. Zentelis.

\section{Aizstāvējuši disertāciju PKMA}

J. Alksnis; Jānis Bērziňš; E. Fērmanis; E. Gartjē; J. Jankovskis; J. Kanskis; V. Klimenko; J. Martinsons; P. Sniḳers; P. Spalviņš; J. Šîrons; E. Zariņ̌ (Mag.pharm.); K. Zuments.

\section{Profesori}

J. Alksnis; J. Bune; E. Bušs; E. Fērmanis; E. Gartjēं; P. Jākobsons;

J. Jankovskis; V. Klimenko; A. Lietavietis; P. Mucenieks; J. Prīmanis; K. Rudzītis; P. Sniḳers; R. V. Sniķers; P. Stradinš; A. Šmidts; K. M. Veidemanis; E. Zariňs.

Goda doktori

J. Alksnis; E. Zarinš.

Generālis

P. Sniķers.

\section{Pulkveži}

J. Alksnis; A. Balodis; Jānis Bērzinš̌; Jēkabs Bērziňš; J. Bune; E. Bušs; N. Grundulis; Krišj̄ānis Kalniň̌; J. Kanskis; J. Martinsons.

Pulkvežleitnanti Latvijas armijā

R. Hjords; J. Manass; J. Paegle; E. Pumpurs; P. Strūve; A. Škipsna; E. Vanags.

\section{Apbalvojumi}

Lāčplēša Kara ordenis

E. Vanags.

\section{Triju Zvaigžnu ordenis}

J. Alksnis; R. Hjords; J. Lỉbietis; J. Manass; J. Prīmanis; P. Sniķers;

P. Strūve; E. Zari̧ı̌s; K. Zentelis.

Darba varonis

E. Bušs.

\section{Lenina ordenis}

J. Jēgermanis; A. Lietavietis (3 gab.); A. Šmidts (3 gab.). 
Krišjānna Barona prēmija

J. Prīmanis; K. M. Veidemanis; E. Zariňš.

Lenina prēmija

A. Lietavietis.

Stalina prēmija

A. Lietavietis; A. Šmidts.

LPSR Valsts prēmija

A. Šmidts.

\section{Goda nosaukumi}

LPSR Nop. bag. zin. darbinieks

J. Bune; K. Rudzìtis; P. Stradiňš; A. Šmidts.

LPSR Nop. bag. ārsts

P. Jākobsons; J. Jēgermanis; J. Liepa; J. Romans.

PSRS Nop. bag. sporta meistars

A. Lietavietis.

\section{Akadēmiju locekḷi}

LPSR ZA akadēmikis

P. Stradiň̌; A. Šmidts

PSRS MZA akadēmikis

A. Lietavietis.

PSRS MZA korespondētājloceklis

P. Stradiň̌; A. Šmidts.

Pieminas iemūžināšana

Publiski pieminekli

P. Stradin̄š (divi).

Pieminas plāksnes un akmeni

J. Alksnis; J. Jēgermanis; J. Lỉbietis; K. Rudzītis; A. Skrinda; P. Sniḳers; P. Stradiňš (četras); P. Strūve.

$\underline{\text { Iestādes }}$

J. Jankovska sanatorija; J. Prīmaṇa muzejs; Brāḷu Skrindu Atašienes vidusskola; P. Stradiña muzejs; P. Stradịna slimnīca; P. Stradiña medicīnas skola; P. Stradina universitāte. 
Ielas

J. Lībietis; K. Rudzītis; Brāli Skrindas; P. Stradinı̌̌ (trīs).

Auditorija

P. Stradinš.

Virsotne un kalnu päreja

A. Lietavietis.

\section{Represēti 1941}

J. Dille; J. Kraulis; E. Pumpurs; P. Strūve (nošauts); E. Vanags.

\section{Emigrējuši 1944}

J. Alksnis; F. Andreika; E. Fērmanis; E. Gartjē; D. Kessels; J. Knostenbergs;

J. Lỉbietis; J. Manass; J. Prīmanis; R.V. Sniḳers; E. Zariņš; L.Zeltkalns.

\section{Nav zināms dz̄ives noslēgums}

A. Balodis; Hermanis Bērzinš; Hugo Bērziňš; Jānis Bērzinš̌; N. Grundulis; Kārlis Kalninš̌; J. Knostenbergs; J. Kraulis; J. Martinsons; A. Mežaks; P. Spalviňš; E. Šable; V. Treknais; K. Zuments.

\section{Hronolog̀iska tabula}

PKMA beiguši latvieši (iestājušies līdz 1918):

1883 J. Martinsons

$1885 \mathrm{~K}$. Zuments

1888 K.M. Lejinš

1889 K. Jankovičs

1893 Krišjānis Kalnịš

1894 P. Spalvin̋š

1896 A. Balodis

1897 A. Liepiňs

1898 E. Bušs

1900 Jānis Bērzinš

1901 N. Grundulis

1901 P. Sniķers

1901 V. Treknais

1907 F. Biezais

1909 Hermanis Bērziňš

1909 A. Skrinda

1911 Kārlis Kalninš

1911 J. Lỉbietis

1911 J. Manass

1912 J. Romans 
1913 A. Šksipsna

1914 J. Bune

1914 J. Dille

1914 A. Kanepājs

1914 V. Ozols

1914 J. Paegle

1914 K. Plaude

1914 E. Šable

1915 J. Biezais

1917 P. Mucenieks

1918 V. Gludinš

1918 J. Prīmanis

1918 R.V. Sniķers

1919 G. Ebels

1919 J. Jēgermanis

1919 P. Stradinš

1921 E. Pumpurs

1922 K. Rudzītis

1922 A. Šmidts

1924 P. Jākobsons

Pielikums ar diskutējamiem precizējumiem

Pēteris Ārons. Stud. PKMA 1914-17?

Vēres: P 232.

Pēteris Balodis. Dzim. 1. dec. 1839 Rīgā priestera ġim. (vai Lielmuižas pag. zemnieka ǵim.). Stud. PKMA 1856-58, nebeidza, Pēterburgas U 1858-62, kad izslēgts un notiesāts par revolucionān darbību. Vēlāk Sibīrijā nometinājumā, zeltrūpnieks. Miris 22. janv. 1918 Blagoveščenskā.

Vēres: M 27; Valeskalns P. Revolucionārais demokrāts Pēteris Balodis.

- Rīga, 1961.

Pēteris Celinskis. Stud. PKMA 1914-?

Vēres: P 232

Džindža. PKMA iestājies 1914, par turpmāko J. Prīmanim datu trūkst, laikam ārsts nav bijis. Varētu būt Pēteris Džindža, dzim. 18. dec. 1893 Raunas pag. amatnieka gím., Rīgas 10. pamatskolas pārzinis un Latvijas Fiziskās audzināšanas pasniedzēju biedrības priekšsēdētājs, 
kas 1926 sadarbībā ar A. Biezinu sācis veidot bezmaksas fakultatīvas koriğējošās vingrošanas grupas Rīgas pamatskolu audzēkṇiem.

Vēres: EVP 149; P 232; Vīksna A., Platkājis E. Zelta skalpelis. - Rīga, $1991^{2}$. - 62. lpp.

Arturs Korps. Stud. PKMA 1906-07, vēlāk jurisprudenci. Nejaukt ar psihiatru Ansi Karpu (1892-1970).

Vēres: LĀP 31; M 117.

Aleksandrs Lozinskis (1868-1961), pazīstams balneologs, beidza PKMA 1893, Dr.med. 1905, Kemeru kūrorta direktors 1904-15, vēlāk profesors Pjatigorskā. Neietilpst š̄ apcerējuma kritērijos.

Vēres: PME 596.

Ozols (bez priekšvārda). Stud. PKMA 1906-07, vēlāk filologiju. Vai nav kāds no revolucionāriem Ozoliem?

Vēres: M 122.

Šmidts no Vijciema, kara ārsts Leišu gubernās. Minēts 1882 Kažoku Dāvja izglītoto latviešu sarakstā. RMS grūti atrast.

Vēres: M 135

Jānis Ūdris. Dzim. 30. aug. Praulienas pag. Stud. PKMA 1906-? Vēl 1913 minēts kā students. Vai nav rados ar kirurği Annu Ũdri (1896-1981), kas nāk no tâs pašas apkaimes?

Vēres: LĀS; M 131.

Kārlis Vanags. Domājams, J. Prīmanis jaucis ar Edgaru Vanagu.

Rūdolfs Vanahs (1862-1931), pazīstams latviešu kirurgs, kas strādāja Pēterburgā, bet ar PKMA saistīts nav, vēlāk profesors Tartu.

Vēres: Deutschbaltisches biographisches Lexikon. - Köln; Wien, 1970. S. 851-852.

Jānis Zirnis. Stud. PKMA 1908, saslimis, varbūt beidzis 1916. Vēres: P 228.

1996. gada 16. aprīīi 